\title{
FIRST REPORT ON CHEMICAL COMPOSITION AND BIOLOGICAL PROPERTIES OF VOLATILE OIL FROM Psidium firmum O. BERG LEAVES
}

\author{
Cassia Cristina Fernandes $^{\mathrm{a}}$, Pietro Chrystal ${ }^{\mathrm{b}}$, Alexandra Cristine Pereira ${ }^{\mathrm{b}}$, Ana Carla Collic, Livia Stenico ${ }^{\mathrm{c}}$, Arthur Barcelos \\ Ribeiro $^{d}$, Iara Silva Squarisi ${ }^{d}$, Ana Carolina Bolela Bovo Candido ${ }^{d}$, Denise Crispim Tavares ${ }^{d}$, Lizandra Guidi Magalhães ${ }^{d}$, \\ Antônio Eduardo Miller Crottic ${ }^{\mathrm{c}}$, Carlos Henrique Gomes Martins ${ }^{\mathrm{e}}$ and Mayker Lazaro Dantas Miranda ${ }^{\mathrm{f}, *, \mathbb{0}}$ \\ anstituto Federal de Educação, Ciência e Tecnologia Goiano, Campus Rio Verde, 75901-970 Rio Verde - GO, Brasil \\ ${ }^{b}$ Instituto Federal de Educação, Ciência e Tecnologia do Sul de Minas Gerais, Campus Pouso Alegre, 37550-000 Pouso Alegre \\ - MG, Brasil \\ 'Departamento de Química, Faculdade de Filosofia, Ciências e Letras de Ribeirão Preto, Universidade de São Paulo, 14049-900 \\ Ribeirão Preto - SP, Brasil \\ ${ }^{\mathrm{d} C e n t r o ~ d e ~ P e s q u i s a ~ e m ~ C i e ̂ n c i a s ~ E x a t a s ~ e ~ T e c n o l o g i a, ~ U n i v e r s i d a d e ~ d e ~ F r a n c a, ~ 14404-600 ~ F r a n c a ~-~ S P, ~ B r a s i l ~}$ \\ 'Departamento de Microbiologia, Instituto de Ciências Biomédicas, Universidade Federal de Uberlândia, 38400-902 Uberlândia \\ - MG, Brasil \\ Instituto Federal de Educação, Ciência e Tecnologia do Triângulo Mineiro, Campus Uberlândia Centro, 38411-104 Uberlândia \\ - MG, Brasil
}

Recebido em 17/11/2020; aceito em 21/12/2020; publicado na web em 03/02/2021

\begin{abstract}
Brazil has the greatest plant diversity in the world. Many species exhibit a wide range of phytochemical compounds which can be exploited in food, agronomic, pharmacological and medicinal plant industries. Therefore, the chemical composition and in vitro bioactivities of volatile oil from Psidium firmum fresh leaves (PfVO) were investigated for the first time. GC-FID and GC-MS analyses revealed 28 compounds in PfVO. The major ones were $\alpha$-selinene (20.8\%), $\beta$-caryophyllene (16.5\%) and nerolidol (10.4\%). Results showed that PfVO affected the growth of Leishmania amazonensis promastigote forms in a dose-dependent manner; its $\mathrm{IC}_{50}$ value was $14.05 \mu \mathrm{g} / \mathrm{mL}$. PfVO also exhibited antibacterial activity against Salmonella enteritidis, Yersinia enterocolitica, Staphylococcus aureus, Pseudomonas aeruginosa and Listeria monocytogenes; MIC values ranged from $25 \mu \mathrm{g} / \mathrm{mL}$ to $250 \mu \mathrm{g} / \mathrm{mL}$. Moreover, PfVO promoted normal cell growth inhibition at $61.02 \pm 1.97 \mu \mathrm{g} / \mathrm{mL}$. Antiproliferative activity was observed against human tumor cell lines; $\mathrm{IC}_{50}$ values of MCF-7 cells, HeLa cells and M059J cells were $47.91 \mu \mathrm{g} / \mathrm{mL}, 73.78 \mu \mathrm{g} / \mathrm{mL}$ and $41.94 \mu \mathrm{g} / \mathrm{mL}$, respectively. Results provided strong evidence of the promising potential of $\mathrm{PfVO}$ as a nature-based antileishmanial, antibacterial and antiproliferative agent.
\end{abstract}

Keywords: Leishmania amazonensis; foodborne bacteria; tumor cell lines; Listeria monocytogenes; Yersinia enterocolitica.

\section{INTRODUCTION}

Volatile oils (VOs) are defined as complex mixtures of volatile compounds (especially monoterpenes, sesquiterpenes, phenylpropanoid derivatives and aliphatic compounds), which can be extracted from different parts of plants, such as flowers, leaves, stems, twigs, seeds, fruits, roots, wood and bark. ${ }^{1}$ In addition, several biological activities, such as insecticidal, antiviral, antioxidant, antimicrobial and antiparasitic ones, have been attributed to VOs. ${ }^{2}$

VOs have been extensively investigated by many research groups worldwide and are considered promising sources of bioactive compounds, which are known for their lower toxicity and higher resistance to microorganisms by comparison with synthetic compounds. ${ }^{3}$ As a result, many VOs have been tested against foodborne pathogens, ${ }^{4}$ tumor cell lines ${ }^{5,6}$ and Leishmania spp., which causes leishmaniasis, one of the main neglected tropical diseases. ${ }^{7,8}$

The genus Psidium (Myrtaceae), popularly known as "araçazeiro" in Brazilian Portuguese, has commercial and economic importance, especially in Brazil, where Psidium species have been widely used as food and for medicinal purposes. ${ }^{9}$ They have also attracted attention due to their botanic characteristics and promising biological activities of their VOs. ${ }^{10,11}$ For instance, in the literature, tea from $P$. firmum leaves exhibits antidiarrheal effects and $P$. firmum fruits have already had their phytotoxic and antioxidant activities reported. ${ }^{12,13}$
To carry on our studies of Psidium species that yield oils with biological properties, ${ }^{14,15}$ volatile oil from $P$. firmum fresh leaves (PfVO) was obtained by hydrodistillation and its antileishmanial, antibacterial and antiproliferative activities were evaluated against the parasite L. amazonensis, several bacterial strains and cancer cell lines. Finally, the chemical composition of PfVO was detected and analyzed by GC-MS and GC-FID. To the best of our knowledge, studies that focus on the chemical composition and biological activities of PfVO have not been reported yet.

\section{EXPERIMENTAL}

\section{Plant material}

Psidium firmum O. Berg (Myrtaceae) fresh leaves were collected in Limeira, (22³3'53'S and 47²4'06”W), São Paulo (SP), Brazil, on October 20th, 2017, at $9 \mathrm{am}$. The plant was identified by the botanist Walnir Gomes Ferreira Junior, Ph. D., and a voucher specimen (GERAES-13) was deposited in the herbarium in the Biology Department at the Instituto Federal de Educação, Ciência e Tecnologia do Sul de Minas Gerais, located in Machado, Minas Gerais (MG), Brazil.

\section{Volatile oil extraction}

PfVO (100 g; fresh leaves) was extracted by hydrodistillation in 
a Clevenger-type apparatus for $3 \mathrm{~h}$. The oil was dried over anhydrous sodium sulfate, filtered and stored in a refrigerator at $5{ }^{\circ} \mathrm{C}$, until both gas chromatography-flame ionization detection (GC-FID) and gas chromatography-mass spectrometry (GC-MS) analyses, besides biological assays, were carried out. PfVO yield (percentage content in fresh matter) was determined by Equation 1.

$$
\operatorname{Yield}(\% F M)=\left[\frac{\text { oil mass }(\mathrm{g})}{\text { plant material mass }(100 \mathrm{~g})}\right] \times 100
$$

\section{Identification of the chemical composition of PfVO}

Volatile oil was dissolved in ethyl ether and analyzed by Gas Chromatography-Flame Ionization Detector (GC/FID) and Gas Chromatography-Mass Spectrometry (GC/MS) using the Shimadzu QP5000 Plus and GCMS2010 Plus (Shimadzu Corporation, Kyoto, Japan) systems. The temperature of the column in the GC/FID was programmed to rise from 60 to $240{ }^{\circ} \mathrm{C}$ at $3{ }^{\circ} \mathrm{C} \mathrm{min}{ }^{-1}$ and was held at $240{ }^{\circ} \mathrm{C}$ for $5 \mathrm{~min}$; the carrier gas was $\mathrm{H}_{2}$ at a flow rate of $1.0 \mathrm{~mL} \mathrm{~min}^{-1}$. The equipment was set to operate in the injection mode; the injection volume of oil solution was $0.1 \mu \mathrm{L}$ (split ratio of $1: 10$ ), and the injector and detector temperatures were 240 and $280^{\circ} \mathrm{C}$, respectively. Percentages of compounds were calculated by the area normalization method, considering response factors. Authentication of compounds found in the essential oil was also determined by standard samples purchased from Sigma Aldrich (Germany). Relative areas consisted of the average of triplicate GC analyses. GC-MS analyses were carried out by a Shimadzu QP2010 Plus (Shimadzu Corporation, Kyoto, Japan) system equipped with an AOC20i autosampler. The column was an RTX-5MS (Restek Co., Bellefonte, PA, USA) fused silica capillary one $(30 \mathrm{~m} \times 0.25 \mathrm{~mm}$ i.d. $\times 0.25 \mu \mathrm{m}$ film thickness $)$. Electron ionization mode occurred at $70 \mathrm{~V}$. and helium $(99.999 \%)$ was employed as the carrier gas at constant flow of $1.0 \mathrm{~mL} \mathrm{~min}{ }^{-1}$. The injection volume was $0.1 \mu \mathrm{L}$ (split ratio of $1: 10$ ). Injector and ion-source temperatures were set at 240 and $280{ }^{\circ} \mathrm{C}$, respectively. The oven temperature program was the same as the one used for GC. Mass spectra were taken at a scan interval of $0.5 \mathrm{~s}$, in the mass range from 40 to $600 \mathrm{Da}$. This methodology was described by Lemes et al. ${ }^{16}$

\section{Antileishmanial activity}

To evaluate antileishmanial activity, L. amazonensis promastigote forms (MHOM/BR/PH8) were maintained in RPMI 1640 (Gibco-Life Technologies, Grand Island, USA) culture medium supplemented with $10 \%$ fetal bovine serum (Cultilab, Campinas, BR), penicillin (100 UI mL $\mathrm{mL}^{-1}$ ) and streptomycin $\left(100 \mu \mathrm{g} \mathrm{mL}^{-1}\right)$ (Gibco-Life Technologies). The methodology used for evaluating the antiLeishmania amazonensis activity of PfVO was the one described by Estevam et al. ${ }^{17}$

\section{Antibacterial activity}

The following pathogenic microorganism strains of foodborne pathogens type were obtained from the American Type Culture Collection (ATCC, Rockville, MD, USA): Salmonella enteritidis (ATCC 13076), Yersinia enterocolitica (ATCC 9610), Staphylococcus aureus (ATCC 9144), Pseudomonas aeruginosa (ATCC 14502) and Listeria monocytogenes (ATCC 15313).

MIC values were determined by the broth microdilution method, as recommended by the literature, ${ }^{18,19}$ with modifications. Assays were performed in Mueller Hinton broth. Inoculums were adjusted to $75 \%$ transmittance at $660 \mathrm{~nm}$, which corresponds to the 0.5 MacFarland

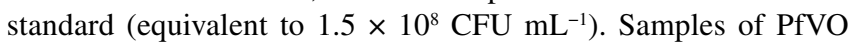

were prepared in absolute ethanol and the initial concentration was $8 \mathrm{mg} \mathrm{mL}^{-1}$. Ethanol provides proper solubility of PfVO in the aqueous culture medium used in the MIC assay. Dilutions were performed in 96-well microplates to obtain serial dilutions of PfVO and reach final concentrations from 0.39 to $400 \mu \mathrm{g} \mathrm{mL}^{-1}$ (eleven serial dilutions). Microplates were incubated at $35 \pm 2{ }^{\circ} \mathrm{C}$ for $24 \mathrm{~h}$. A solution of resazurin $(0.02 \%)$ was used for determining microbial growth, which was visually indicated by changes in color (from blue to pink). The lowest concentration at which color did not vary was considered the MIC value. ${ }^{20}$ Positive controls were penicillin, streptomycin and ampicillin (both from Sigma-Aldrich, St. Louis, MO) for Grampositive and Gram-negative bacteria, respectively, at concentrations ranging from 1.25 to $5.9 \mu \mathrm{g} \mathrm{mL}^{-1}$ (Table 1). The antimicrobial assay was performed in triplicate. The solvent (absolute ethanol), antimicrobial standards and culture media were used as controls.

Table 1. Minimum Inhibitory Concentration (MIC) values $(\mu \mathrm{g} / \mathrm{mL}$ ) of volatile oil from P. firmum fresh leaves (PfVO) against selected foodborne pathogens

\begin{tabular}{lcccc}
\hline bacteria & MIC & MIC & MIC & MIC \\
& PfVO & Penicillin & $\begin{array}{c}\text { Streptomycin } \\
\text { Ampicillin }\end{array}$ \\
\hline Salmonella enteritidis & 100 & 5.9 & $\mathrm{a}$ & 1.25 \\
Yersinia enterocolitica & 62.5 & $\mathrm{a}$ & 5.9 & 1.25 \\
Staphylococcus aureus & 125 & 5.9 & $\mathrm{a}$ & 1.25 \\
Pseudomonas aeruginosa & 250 & $\mathrm{a}$ & 5.9 & 1.25 \\
Listeria monocytogenes & 25 & 5.9 & $\mathrm{a}$ & 1.25 \\
\hline
\end{tabular}

a: Not rated. Positive controls: penicillin, streptomycin and ampicillin.

\section{Antiproliferative activity}

In this study, three different human tumor cell lines were used: breast adenocarcinoma (MCF-7), cervical adenocarcinoma (HeLa) and glioblastoma (M059J). A normal human cell line (lung fibroblasts, GM07492A) was included to evaluate whether the natural product under investigation had selective activity. Cell lines were maintained as monolayers in plastic culture medium (HAM-F10 + DMEM, $1: 1$, Sigma-Aldrich), supplemented with $10 \%$ fetal bovine serum (Nutricell), antibiotics $\left(0.01 \mathrm{mg} \mathrm{mL}^{-1}\right.$ streptomycin and $0.005 \mathrm{mg} \mathrm{mL}^{-1}$ penicillin; Sigma-Aldrich) and $2.38 \mathrm{mg} / \mathrm{mL}$ Hepes (Sigma-Aldrich). Cells were incubated at $36.5^{\circ} \mathrm{C}$ in a humidified $5 \% \mathrm{CO} 2$ atmosphere.

Antiproliferative activity was measured by the in vitro Toxicology Colorimetric Assay Kit (XTT; Roche Diagnostics), in agreement with the manufacturer's instructions. In the experiments, cells (104 cells/well) were placed on 96-well microplates. Each well got $100 \mu \mathrm{L}$ HAM-F10/DMEM medium with volatile oil at concentrations ranging from 3.91 to $500 \mu \mathrm{g} / \mathrm{mL}$. Negative (no treatment), solvent (0.02\% DMSO, dimethylsulfoxide, Sigma-Aldrich) and positive (doxorubicin, DXR, Pharmacia Brasil Ltda.) controls were included. After incubation at $36.5^{\circ} \mathrm{C}$ for $24 \mathrm{~h}$, the culture medium was removed. Cells were washed with $100 \mu \mathrm{L}$ PBS (phosphate buffered saline), to remove treatments, and then exposed to $100 \mu \mathrm{L}$ culture medium HAM-F10 without phenol red. Afterwards, $25 \mu \mathrm{L}$ XTT was added and cells were incubated at $36.5^{\circ} \mathrm{C}$ for $17 \mathrm{~h}$. Sample absorbance was determined by a multi-plate reader (ELISA - Tecan - SW Magellan vs 5.03 STD 2P) at wavelength of $450 \mathrm{~nm}$ and reference length of $620 \mathrm{~nm}$. Antiproliferative activity was assessed with the use of $\mathrm{IC}_{50}$, the concentration that was able to inhibit $50 \%$ of the cell line growth as a response parameter, which was calculated by the GraphPad Prism program by plotting cell survival against the respective concentrations of the natural product under investigation. One-way ANOVA was used for comparing means $(\mathrm{P} \leq 0.05)$. Experiments were performed 
in triplicate. The selectivity index was calculated by dividing the $\mathrm{IC}_{50}$ value of the volatile oil obtained for GM07492A cells by the $\mathrm{IC}_{50}$ value obtained for the tumor cell line. This methodology was described by Alves et al. ${ }^{21}$

\section{RESULTS AND DISCUSSION}

\section{Yield and chemical composition of PfVO}

PfVO was obtained as a faint colorless oil with aromatic odor in $0.5 \%$ yield $(\mathrm{w} / \mathrm{w})$. Chemical components of PfVO, which were identified by GC-MS and GC-FID analyses, are listed in Table 2. Twenty-eight volatile compounds, corresponding to $97.5 \%$ of total constituents, were identified. Sesquiterpene hydrocarbons $(61.4 \%)$ and oxygenated sesquiterpenes (27.5\%) predominated in PfVO, while $\alpha$-Selinene (20.8\%), $\beta$-caryophyllene (16.5\%) and nerolidol (10.4\%) were its major compounds. $\alpha$-Selinene and $\beta$-caryophyllene were also reported as the main components in volatile oil extracted from

Table 2. Compounds of volatile oil from P. firmum fresh leaves (PfVO) identified by GC-MS and GC-FID

\begin{tabular}{|c|c|c|c|c|}
\hline Compounds & RT (min) & $\%$ RA & $\mathrm{RI}_{\mathrm{exp}}$ & $\mathrm{RI}_{\text {lit }}$ \\
\hline Eucalyptol & 16.13 & 2.2 & 1033 & 1033 \\
\hline$\gamma$-Terpinene & 17.87 & 0.1 & 1061 & 1062 \\
\hline Linalool & 20.41 & 0.2 & 1097 & 1098 \\
\hline Hydrocinnamaldehyde & 23.96 & 1.8 & 1158 & 1160 \\
\hline Terpinene-4-ol & 25.25 & 0.4 & 1175 & 1177 \\
\hline$\alpha$-Terpineol & 25.96 & 2.0 & 1188 & 1189 \\
\hline$\alpha$-Fenchyl acetate & 28.08 & 0.4 & 1215 & 1217 \\
\hline Bornyl acetate & 30.76 & 0.8 & 1284 & 1285 \\
\hline trans-Pinocarveyl acetate & 31.27 & 0.2 & 1297 & 1297 \\
\hline$\alpha$-Terpinyl acetate & 33.58 & 0.3 & 1349 & 1349 \\
\hline Neryl acetate & 34.14 & 0.2 & 1362 & 1365 \\
\hline$\alpha$-Copaene & 34.54 & 3.2 & 1374 & 1376 \\
\hline Geranyl acetate & 35.06 & 0.2 & 1383 & 1383 \\
\hline$\alpha$-Gurjunene & 35.98 & 1.1 & 1408 & 1409 \\
\hline$\beta$-Caryophyllene & 36.53 & 16.5 & 1419 & 1419 \\
\hline$\beta$-Humulene & 37.20 & 4.8 & 1438 & 1440 \\
\hline$\gamma$-Selinene & 38.97 & 5.0 & 1484 & 1484 \\
\hline$\alpha$-Selinene & 39.67 & 20.8 & 1493 & 1494 \\
\hline$\beta$-Bisabolene & 39.88 & 0.7 & 1508 & 1509 \\
\hline$\delta$-Cadinene & 40.55 & 7.4 & 1523 & 1524 \\
\hline trans- $\gamma$-Bisabolene & 41.14 & 0.9 & 1540 & 1541 \\
\hline$\alpha$-Muurolene & 41.03 & 0.6 & 1594 & 1494 \\
\hline$\alpha$-Calacorene & 41.25 & 0.2 & 1547 & 1548 \\
\hline Nerolidol & 42.27 & 10.4 & 1564 & 1564 \\
\hline Caryophyllene oxide & 42.84 & 3.3 & 1581 & 1581 \\
\hline Ledol & 43.60 & 1.1 & 1563 & 1565 \\
\hline$\alpha$-Cadinol & 45.48 & 7.1 & 1653 & 1653 \\
\hline Juniper camphor & 45.74 & 5.6 & 1690 & 1691 \\
\hline Monoterpene hydrocarbons & & 2.5 & & \\
\hline Oxygenated monoterpenes & & 4.3 & & \\
\hline Sesquiterpene hydrocarbons & & 61.4 & & \\
\hline Oxygenated sesquiterpenes & & 27.5 & & \\
\hline Phenylpropanoids & & 1.8 & & \\
\hline Total & & 97.5 & & \\
\hline \multicolumn{5}{|c|}{$\begin{array}{l}\mathrm{RI}_{\text {exp }}: \text { Retention index relative to } n \text {-alkanes }\left(\mathrm{C}_{8}-\mathrm{C}_{20}\right) \text { on } \mathrm{Rtx}-5 \mathrm{MS} \\
(30 \mathrm{~m} \times 0.25 \mathrm{~mm} ; 0.250 \mu \mathrm{m}) \text { column; } \mathrm{RI}_{\mathrm{lit}}: \text { Retention index found in the } \\
\text { literature; } 46 \% \mathrm{RA} \text { : relative area (peak area relative to the total peak area in } \\
\text { the GC-FID chromatogram). }\end{array}$} \\
\hline
\end{tabular}

P. striatulum leaves. ${ }^{22}$ High nerolidol content was also reported in volatile oil from $P$. guajava leaves collected in Nepal. ${ }^{23}$

Although the chemical composition of VOs is determined by genetic factors, other factors can also promote significant changes in secondary metabolite production. Different stimulation in the environment where plants live can direct their metabolic pathway and promote biosynthesis of different compounds. These factors include plant microorganisms, plant-plant interactions, age and stage of development. Besides, abiotic factors, such as luminosity, temperature, rainfall, nutrition, harvest time and season, exert influence on plants, as well as harvest and post-harvest techniques. These factors can act separately or in combination. ${ }^{24}$

It is remarkable that plants that belong to the genus Psidium have always drawn researchers' attention due to their botanical, chemical and pharmacological aspects. For instance, linalool is relevant in the volatile oil from $P$. myrsinites, since this monoterpene is important as a fragrance fixer to the perfume industry. ${ }^{25}$ Chemical analyses of volatile oils from $P$. salutare, $P$. striatulum, $P$. guajava and $P$. cattleianum have already revealed their high concentrations of the bioactive sesquiterpene $\beta$-caryophyllene. On the other hand, juicy fruit from $P$. acutangulum have become popular food on the seashore in Paraná state, Brazil. ${ }^{25}$ In short, several biological activities exhibited by plants that belong to the genus Psidium have been attributed to components of volatile oils, which are mostly found in leaves. ${ }^{25}$

\section{Antileishmanial activity}

Antileishmanial activity of PfVO was evaluated against Leishmania amazonensis promastigote forms. Results showed that PfVO affected promastigote growth in a dose-dependent manner (Table 3). $\mathrm{IC}_{50}$ value of PfVO was $14.05 \mu \mathrm{g} \mathrm{mL}^{-1}$, while the one of amphotericin B was $0.011 \mu \mathrm{g} \mathrm{mL}^{-1}$ (positive control). In current literature, natural products whose $\mathrm{IC}_{50}$ values range between 10 and $50 \mu \mathrm{g} \mathrm{mL}^{-1}$ are considered active. ${ }^{26}$

Thus, these results show that PfVO exhibits leishmanicidal activity. Previous studies demonstrated that extracts and fractions from Psidium brownianum and Psidium guajava showed low toxicity towards fibroblasts and moderate activities against $T$. cruzi, L. brasiliensis and L. infantum. ${ }^{27}$ Similar results were produced by EO from Myrciaria plinioides, another plant belonging to the Myrtaceae family. ${ }^{28}$ On the other hand, EO from Psidium salutare leaves was considered active, with $\mathrm{IC}_{50}$ value 5-fold higher than that demonstrated by PfVO ${ }^{29}$ Leishmanicidal effects of PfVO might be attributed to its major chemical compounds, such as $\beta$-caryophyllene and nerolidol, whose leishmanicidal activity has been already described in the literature..$^{30,31}$

\section{Antibacterial activity}

Foodborne diseases are caused by the ingestion of decayed food, contaminated by microorganisms, mainly harmful bacteria. Antibacterial activity of PfVO against some foodborne pathogens is shown in Table 1. Based on the criteria established by Machado et al. ${ }^{32}$ natural products with MIC values between 10 and $100 \mu \mathrm{g} \mathrm{mL}^{-1}$ were considered good, while values between 100 and $500 \mu \mathrm{g} \mathrm{mL}^{-1}$ were considered moderate. All bacteria under investigation exhibited inhibitory activity, with MIC values ranging from 25 to $250 \mu \mathrm{g} \mathrm{mL} \mathrm{m}^{-1}$.

In this study, PfVO was effective against the following foodborne pathogens: Salmonella enteritidis $\left(\mathrm{MIC}=100 \mu \mathrm{g} \mathrm{mL} \mathrm{m}^{-1}\right.$ ), Yersinia enterocolitica ( $\mathrm{MIC}=62.5 \mu \mathrm{g} / \mathrm{mL})$, Staphylococcus aureus $\left(\mathrm{MIC}=125 \mu \mathrm{g} \mathrm{mL}^{-1}\right)$, Pseudomonas aeruginosa $\left(\mathrm{MIC}=250 \mu \mathrm{g} \mathrm{mL}^{-1}\right)$ and Listeria monocytogenes $\left(\mathrm{MIC}=25 \mu \mathrm{g} \mathrm{mL}^{-1}\right.$ ). Considering the diversity of chemical compounds found in PfVO, it is most likely that 
Table 3. In vitro leishmanicidal activity of volatile oil from P. firmum fresh leaves (PfVO) against L. amazonensis promastigote forms

\begin{tabular}{|c|c|c|c|c|c|c|}
\hline & \multicolumn{5}{|c|}{ Concentrations $(\mu \mathrm{g} / \mathrm{mL}) \pm$ Standard deviation } & \multirow{2}{*}{$\mathrm{IC}_{50}\left(\mu \mathrm{g} \mathrm{mL} L^{-1}\right)$} \\
\hline & 50 & 25 & 12.5 & 6.25 & 3.12 & \\
\hline \multirow[t]{2}{*}{ PfVO } & $100 \pm 0.00$ & $72.57 \pm 25.69$ & $45.78 \pm 2.05$ & $14.45 \pm 2.05$ & $5.69 \pm 1.26$ & $14.05 \pm 2.10$ \\
\hline & 0.19 & 0.095 & 0.047 & 0.023 & 0.011 & \\
\hline Amph. B & $99.88 \pm 0.60$ & $78.33 \pm 24.43$ & $68.74 \pm 21.97$ & $54.67 \pm 17.77$ & $42.44 \pm 20.97$ & $0.011 \pm 0.34$ \\
\hline
\end{tabular}

*Positive control (Amph. B = Amphotericin B).

its antibacterial activity is not attributable to one specific mechanism but that there are several targets in the cell. ${ }^{33}$

Antibacterial activity of PfVO against Listeria monocytogenes $\left(\mathrm{MIC}=25 \mu \mathrm{g} \mathrm{mL}^{-1}\right)$ and Yersinia enterocolitica $\left(\mathrm{MIC}=62.5 \mu \mathrm{g} \mathrm{mL}^{-1}\right)$ is a noteworthy result. The former is a bacterium which is commonly detected in soil, water, sewer, plants and food. Its resistance is observed in certain conditions, such as low $\mathrm{pH}$ values, very low temperatures and salting processes. ${ }^{34}$ Food contamination by L. monocytogenes is a serious concern for food industries, which have employed VOs as natural antimicrobial additives. ${ }^{34}$ Gastroenteritis caused by $Y$. enterocolitica, which is the most common disease that affects people worldwide, causes fever, abdominal pain and diarrhea. ${ }^{35}$ It is estimated that more than 110,000 people are annually infected by $Y$. enterocolitica in the United States. In most cases, infection occurs by means of contaminated food. ${ }^{36}$ Therefore, antibacterial activity of PfVO reinforces the potential of VOs as bactericidal agents, especially against Listeria monocytogenes and Yersinia enterocolitica. ${ }^{37}$

\section{Antiproliferative activity}

Results of antiproliferative activity of PfVO are shown in Table 4. $\mathrm{IC}_{50}$ values of PfVO in tumor cell lines MCF-7, HeLa and M059J were $47.91,73.78$ and $41.94 \mu \mathrm{g} / \mathrm{mL}$, respectively, while in GM07492A cell line (normal cell line), it was $61.02 \mu \mathrm{g} \mathrm{mL}^{-1}$. In MCF-7 and M059J, PfVO selectivity index (SI) values were 1.27 and 1.45 , respectively. This study is the first report of antiproliferative activity of PfVO.

Table 4. Half maximal inhibitory concentration $\left(\mathrm{IC}_{50}\right)\left(\mu \mathrm{g} \mathrm{mL} \mathrm{L}^{-1}\right)$ and selectivity index (SI) of volatile oil from P. firmum fresh leaves (PfVO) against different cell lines

\begin{tabular}{lccccc}
\hline \multirow{2}{*}{ Cell line } & \multicolumn{4}{c}{ Treatment $(\mu \mathrm{g} / \mathrm{mL})$} \\
\cline { 2 - 3 } \cline { 2 - 3 } \cline { 5 - 6 } & \multicolumn{2}{c}{ PfVO } & & \multicolumn{2}{c}{ DXR } \\
\cline { 2 - 3 } \cline { 5 - 6 } GM07492A & $61.02 \pm 1.97$ & - & & $0.50 \pm 0.20$ & - \\
MCF-7 & $47.91 \pm 4.7^{7} \mathrm{a}$ & 1.27 & & $62.10 \pm 2.00$ & - \\
HeLa & $73.78 \pm 0.47^{\mathrm{a}}$ & - & & $5.30 \pm 1.30$ & - \\
M059J & $41.94 \pm 1.80^{\mathrm{a}}$ & 1.45 & & $16.20 \pm 2.50$ & - \\
\hline
\end{tabular}

Doxorubicin (DXR) was used as positive control. GM07492A (human lung fibroblasts), MCF-7 (human breast adenocarcinoma), HeLa (human cervical adenocarcinoma) and M059J (human glioblastoma). Selectivity index is the ratio between the $\mathrm{IC}_{50}$ value of PfVO obtained for GM07492A cells and the one of the tumor cell line. Values are mean $\pm \mathrm{SD}, \mathrm{n}=3$. ${ }^{\text {a Significantly different }}$ from the normal cell line (GM07492A) $(P<0.05)$.

Cytotoxic activity of PfVO may be due to its high content of sesquiterpenes, mainly the high percentages of $\beta$-caryophyllene and nerolidol, some of its major chemical constituents. The high potential of sesquiterpenes as cytotoxic and anticancer agents has recently been demonstrated, ${ }^{38-40}$ while a large number of these compounds has been evaluated in cancer clinical trials. ${ }^{41} \beta$-caryophyllene and nerolidol are reported to have significant cytotoxic activity. ${ }^{42-45}$
Results found by Dahham et al. ${ }^{44}$ suggest that cytotoxicity induced by $\beta$-caryophyllene can be attributed to its apoptotic properties via DNA fragmentation and mitochondrial pathways. According to Chan et al., ${ }^{45}$ the sesquiterpene nerolidol could lead to cell death as the result of mitochondrial dysfunction and of its high ability to disrupt cell membrane.

In sum, results showed that PfVO exerted selective and cytotoxic activity against tumor cell lines. Therefore, PfVO can be considered a promising source in the development of new antitumor drugs.

\section{CONCLUSIONS}

Volatile oil from Psidium firmum fresh leaves (PfVO), whose chemical composition is reported for the first time, contains $\alpha$-selinene $(20.8 \%), \beta$-caryophyllene $(16.5 \%)$ and nerolidol $(10.4 \%)$ as its major compounds. PfVO showed not only promising antileishmanial activity against promastigote forms of L. amazonensis, but also good antibacterial activity against two foodborne pathogens, Listeria monocytogenes and Yersinia enterocolitica, and moderate activity against all other bacteria under investigation. Besides, PfVO exhibited selective and cytotoxic activity against tumor cell lines. These results corroborate the idea that volatile oil from this species of Myrtaceae - Psidium firmum -, are promising in in vitro tests, but require further studies, such as toxicological tests and others that are capable of evaluating their in vivo biological potential.

\section{ACKNOWLEDGMENTS}

The authors are grateful to IFSULDEMINAS - Campus Pouso Alegre, IFGOIANO - Campus Rio Verde, IFTM- Campus Uberlândia Centro, Universidade de Franca (UNIFRAN) and FAPESP (grant no. 2007/54241-8) for their financial support.

\section{REFERENCES}

1. Nieto, G.; Medicines 2017, 4, 63.

2. Raut, J. S.; Karuppayil, S. M.; Ind. Crops Prod. 2014, 62, 250.

3. Piras, A.; Gonçalves, M.J.; Alves. J.; Falconieri, D.; Porcedda, S.; Maxia, A.; Salgueiro, L.; Ind. Crops Prod. 2018, 113, 89.

4. Akarca, G.; Ind. Crops Prod. 2019, 137, 285.

5. Padalia, R. C.; Verma, R. S.; Chauhan, A.; Singh, V. R, Goswami, P.; Singh, S.; Verma, S. K.; Luqman, S.; Chanotiya, C. S.; Darokar, M. P.; Ind. Crops Prod. 2018, 112, 749.

6. Silva, E. A. J.; Estevam, E. B. B.; Silva, T. S.; Nicolella, H. D.; Furtado, R. A.; Alves, C. C. F.; Souchie, E. L.; Martins, C. H. G.; Tavares, D. C.; Barbosa, L. C. A.; Miranda, M. L. D.; Braz. J. Biol. 2019, 79, 697.

7. Alcoba, A. E. T.; Melo, D. C.; Andrade, P. M; Dias, H. J.; Pagotti, M. C.; Magalhães, L. G.; Júnior, W. G. F.; Crotti, A. E. M.; Miranda, M. L. D.; Nat. Prod. Res. 2018, 32, 2865.

8. Silva, V. D.; Almeida-Souza, F.; Teles, A. M.; Neto, P. A.; MondegoOliveira, R.; Filho, N. E. M.; Taniwaki, N. N.; Abreu-Silva, A. L.; Calabrese, K. S.; Filho, V. E. M.; Ind. Crops Prod. 2018, 119, 201. 
9. Oliveira, E. F.; Bezerra, D. G.; Santos, M. L.; Rezende, M. H.; Paula, J. A. M.; Braz. J. Pharmacogn. 2017, 27, 407.

10. Tuler, A. C.; Carrijo, T. T.; Ferreira, M. F. S.; Peixoto, A. L.; Rodriguésia 2017, 68, 1791

11. Figueiredo, P. L. B.; Silva, R. C.; Silva, J. K. R.; Suemitsu, C.; Mourão, R. H. V.; Maia, J. G. S.; Chem. Cent. J. 2018, 12, 52.

12. Hamacek, F. R.; Santos, P. R. G.; Cardoso, L. M.; Ribeiro, S. M. R.; Sant'Ana, H. M. P.; Fruits 2013, 68, 467.

13. Peres, M. T. L. P.; Lopes, J. R. R.; Silva, C. B.; Cândido, A. C. S.; Simionatto, E.; Cabral, M. R. P.; Oliveira, R. M.; Facco, J. T.; Cardoso, C. A. L.; Simas, P. H.; Acta Bot. Bras. 2013, 27, 836.

14. Dias, A. L. B.; Batista, H. R. F.; Estevam, E. B. B.; Alves, C. C. F.; Forim, M. R.; Nicolella, H. D.; Furtado, R. A.; Tavares, D. C.; Silva, T. S.; Martins, C. H. G.; Miranda, M. L. D.; Nat. Prod. Res. 2019, 33, 2566.

15. Chrystal, P.; Pereira, A. C.; Fernandes, C. C.; Souza, J. M.; Martins, C. H. G.; Potenza, J.; Crotti, A. E. M.; Miranda, M. L. D.; Braz. Arch. Biol. Technol. 2020, 63, e20190196.

16. Lemes, R. S.; Alves, C. C. F.; Estevam, E. B. B.; Santiago, M. B.; Martins, C. H. G.; Santos, T. C. L.; Crotti, A. E. M.; Miranda, M. L. D.; An. Acad. Bras. Ciênc. 2018, 90, 1285.

17. Estevam, E. B. B.; Deus, I. P. B.; Silva, V. P.; Silva, E. A. J.; Alves, C. C. F.; Alves, J. M.; Cazal, C. M.; Magalhães, L. G.; Pagotti, M. C.; Esperandim, V. R.; Souza, A.F.; Miranda, M. L. D.; An. Acad. Bras. Ciênc. 2017, 89, 3005.

18. Clinical Laboratory Standards Institute (CLSI). 2012. Performance Standards for Antimicrobial Susceptibility Testing; Approved Standards, $11^{\text {th }}$ ed. Wayne, PA, USA (CLSI document M100-S22).

19. Wang, F.; Wei, F.; Song, C.; Jiang, B.; Tian, S.; Yi, J.; Yu, C.; Song, Z.; Sun, L.; Bao, Y.; Wu, Y.; Huang, Y.; Li, Y.; Ind. Crops Prod. 2017, 109, 358.

20. Hussain, A. I.; Anwar, F.; Nigam, P. S.; Sarker, S. D.; Moore, J. E.; Rao, J. R.; Mazumdar, A.; LWT - Food Sci. Technol. 2011, 44, 1199.

21. Alves, C. C. F.; Oliveira, J. D.; Estevam, E. B. B.; Xavier, M. N.; Nicolella, H. D.; Furtado, R. A.; Tavares, D. C.; Miranda, M. L. D.; Braz. J. Biol. 2020, 80, 290.

22. Silva, J. D.; Luz, A. I. R.; Silva, M. H. L.; Andrade, E. H. A.; Zoghbi, M. G. B.; Maia, J. G. S.; Flavour Frag. J. 2003, 18, 240.

23. Satyal, P.; Paudel, P.; Lamichhane, B.; Setzer, W. N.; Am. J. Essent. Oil Nat. Prod. 2015, 3, 11.

24. Barra, A. Nat. Prod. Commun. 2009, 4, 1147.

25. Durães, E. R. B.; Paula, J. A. M.; Naves, P. L. F.; Revista Processos Químicos 2015, 9, 33

26. Andrade, P. M.; Melo, D. C.; Alcoba, A. E. T.; Júnior, W. G. F.; Pagotti, M. C.; Magalhães, L. G.; Santos, T. C. L.; Crotti, A. E. M.; Alves, C. C. F.; Miranda, M. L. D.; An. Acad. Bras. Ciênc. 2018, 90, 2671.
27. Souza, C. E. S.; Silva, A. R. P.; Gomez, M. C. V.; Rolóm, M.; Coronel, C.; Costa, J. G. M.; Sousa, A. K.; Rolim, L. A.; Souza, F. H. S.; Coutinho, H. D. M.; Acta Trop. 2017, 176, 380.

28. Kauffmann, C.; Giacomin, A. C.; Arossi, K.; Pacheco, L. A.; Hoehne, L.; Freitas, E. M.; Machado, G. M. C.; Cavalheiro, M. M. C.; Gnoatto, S. C. B.; Ethur, E. M.; Braz. J. Pharm. Sci. 2019, 55, e17584.

29. Kauffmann, C.; Ethur, E. M.; Buhl, B.; Scheibel, T.; Machado, G. M. C.; Cavalheiro, M. M. C.; Environ. Nat. Resour. Res. 2016, 6, 18.

30. Soares, D. C.; Portella, N. A.; Ramos, M. F. S.; Siani, A. C.; Saraiva, E. M.; Evid. Based Complement. Altern. Med. 2013, ID 761323.

31. Arruda, D. C.; D’Alexandri, F. L.; Katzin, A. M.; Uliana, S. R. B.; Antimicrob. Agents Chemother. 2005, 49, 1679.

32. Machado, K. E.; Filho, V. C.; Tessarolo, M. L.; Mallmann, R.; MeyreSilva, C.; Cruz, A. B.; Pharm. Biol. 2005, 43, 636

33. Burt, S.; Int. J. Food Microbiol. 2004, 94, 223.

34. Leonard, C. M.; Virijevic, S.; Regnier, T.; Combrinck, S.; S. Afr. J. Bot. 2010, 76, 676.

35. Rahman, A.; Bonny, T. S.; Stonsaovapak, S.; Ananchaipattana, C.; J. Phatol. 2011, ID 239391.

36. Scallan, E.; Hoekstra, R. M.; Angulo, F. J.; Tauxe, R. V.; Widdowson, M. A.; Roy, S. L.; Jones, J. L.; Griffin, P. M.; Emerg. Infect. Dis. 2011, 17,7 .

37. Firouzi, R.; Shekarforoush, S. S.; Nazer, A. H. K.; Borumand, Z.; Jooyandeh, A. R.; J. Food Prot. 2007, 70, 2626.

38. Kolli, E. H.; León, F.; Benayache, F.; Estévez, S.; Quintana, J.; Estévez, F.; Brouard, I.; Bermejo, J.; Benayache, S.; J. Braz. Chem. Soc. 2012, 23, 977.

39. Gohari, A. R.; Mosaddegh, M.; Naghibi, F.; Eslami-Tehrani, B.; Pirani, A.; Hamzeloo-Moghadam, M.; Read, R. W.; An. Acad. Bras. Ciênc. 2015, 87, 777.

40. Ren, Y.; Yu, J.; Douglas Kinghorn, A.; Curr. Med. Chem. 2016, 23, 2397.

41. Ghantous, A.; Gali-Muhtasib, H.; Vuorela, H.; Saliba, N. A.; Darwiche, N.; Drug Discov. Today. 2010, 15, 668.

42. Jun, N. J.; Mosaddik, A.; Moon, J. Y.; Ki-Chang, J.; Dong-Sun, L.; Ahn, K. S.; Cho, S. K.; Rec. Nat. Prod. 2011, 5, 242.

43. Ferreira, F. M.; Palmeira, C. M.; Oliveira, M. M.; Santos, D.; Simões, A. M.; Rocha, S. M.; Coimbra, M. A.; Peixoto, F.; Toxicol. In Vitro 2012. 26, 189.

44. Dahham, S.; Tabana, Y.; Iqbal, M.; Ahamed, M.; Ezzat, M.; Majid, A.; Majid, A.; Molecules 2015, 20, 11808

45. Chan, W. K.; Tan, L. T. H.; Chan, K. G.; Lee, L. H.; Goh, B. H.; Molecules 2016, 21, 529.

46. Adams, R. P.; Identification of Essential Oil Components by Gas Chromatography/Quadrupole Mass Spectroscopy, $4^{\text {th }}$ ed., Allured Publishing Corporation: Carol Stream, 2007, 804 p. 